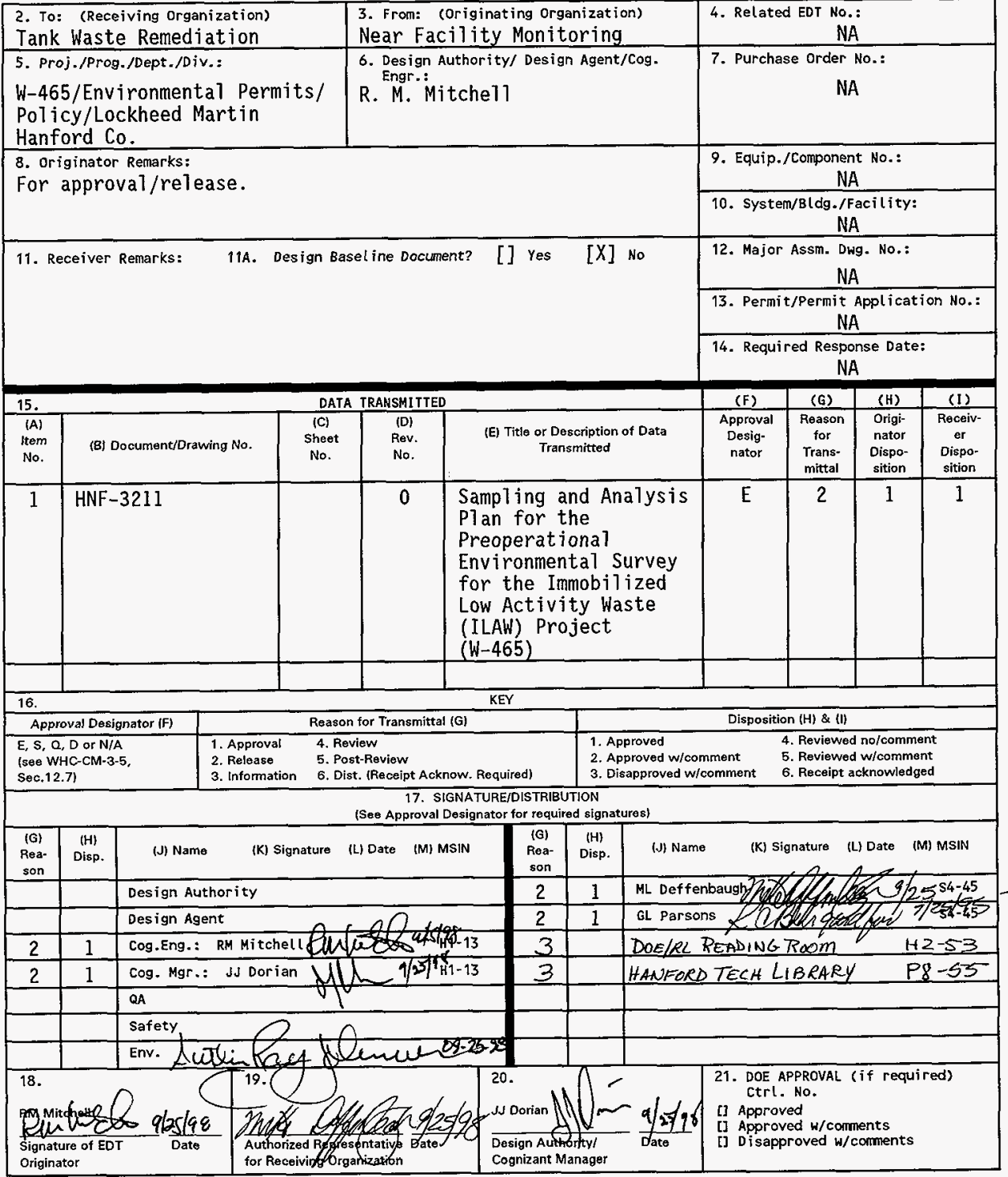




\section{Sampling and Analysis Plan for the Preoperational Environmental Survey for the Immobilized Low Activity Waste (ILAW) Project (W-465)}

R. M. Mitchel1, B. M. Markes, C. J. Perkins, and A. R. Johnson Waste Management Federal Services, Inc., Northwest Operations, Richland, WA 99352

U.S. Department of Energy Contract DE-ACO6-96RL13200

$\begin{array}{llll}\text { EDT/ECN: } & \text { EDT } 622966 & \text { UC: } 2070 \\ \text { Org Code: } & \text { O3E00 } & \text { Charge Code: } & \text { D4DNM/HJ } 260100 \\ \text { B\&R Code: } & \text { EW } 3130010 & \text { Total Pages: } 34\end{array}$

Key Words: Sampling Analysis, Characterization, Samples, W-465, Environmental, ILAW, Preoperationa1

Abstract: This document provides a detailed description of the Sampling and Analys is Plan for the Preoperational Survey to be conducted at the Immobilized Low Activity Waste (ILAW) Project Site in the 200 East Area.

TRADEMARK DISCLAIMER. Reference herein to any specific comercial product, process, or service by trade name, trademark, manufacturer, or otherwise, does not necessarily constitute or imply its endorsement, recommendation, or favoring by the United States Government or any agency thereof or its contractors or subcontractors.

Printed in the United States of America. To obtain copies of this document, contact: Document Contral Services, P.0. Box 950, Mailstop H6-08, Richland WA 99352, Phone (509) 372-2420; Fax (509) 376-4989.
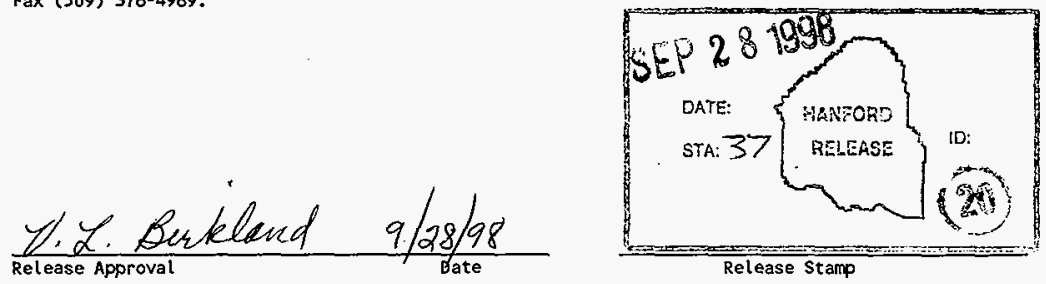

Approved for Public Release 
HNF-3211 Rev. 0

\section{SAMPLING AND ANALYSIS PLAN FOR THE PREOPERATIONAL ENVIRONMENTAL SURVEY FOR THE IMMOBILIZED LOW ACTIVITY WASTE (ILAW) PROJECT (W-465)}

R. M. Mitchell

B. M. Markes

C. J. Perkins

A. R. Johnson

September 1998

Waste Management Federal Services, Inc.,

Northwest Operations

Richland, Washington 


\section{CONTENTS}

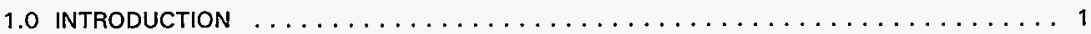

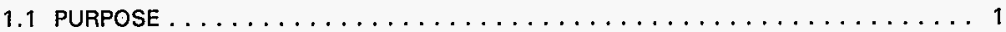

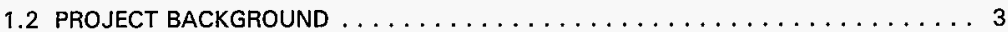

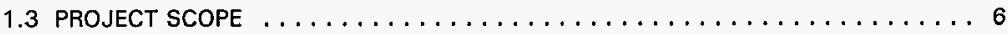

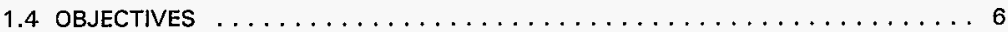

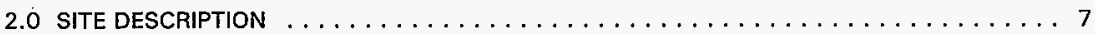

3.0 BACKGROUND ENVIRONMENTAL INFORMATION $\ldots \ldots \ldots \ldots \ldots \ldots \ldots$

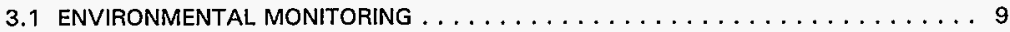

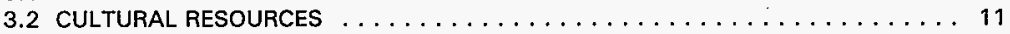

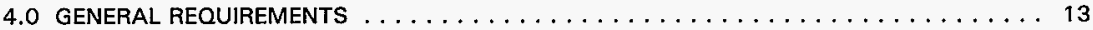

4.1 HANFORD GENERAL REQUIREMENTS $\ldots \ldots \ldots \ldots \ldots \ldots \ldots \ldots \ldots \ldots$

4.2 ILAW PROJECT (W-465) FACILITIES GENERAL REQUIREMENTS $\ldots \ldots \ldots \ldots$

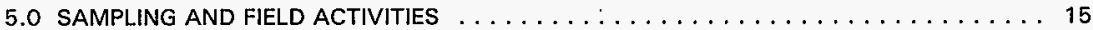

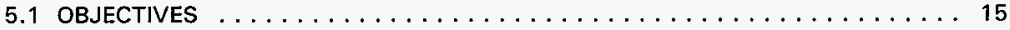

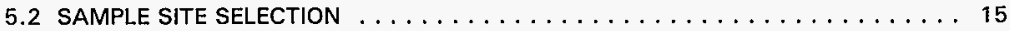

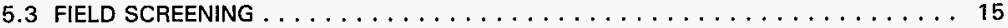

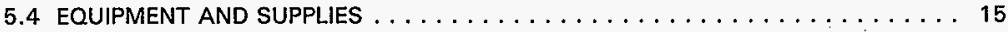

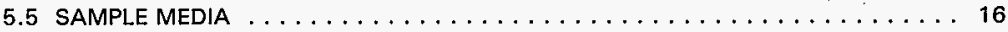

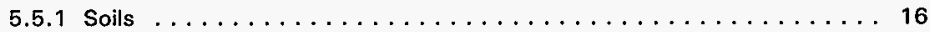

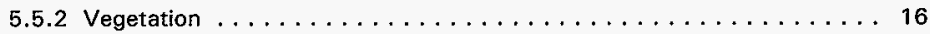

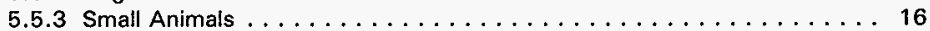

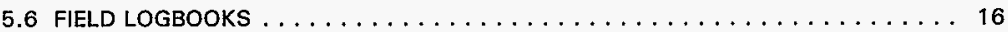

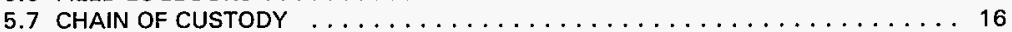

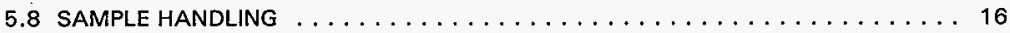

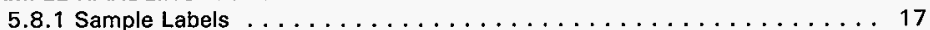

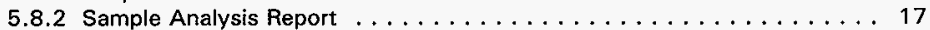

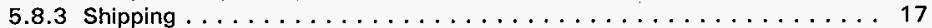

5.9 DECONTAMINATION $\ldots \ldots \ldots \ldots \ldots \ldots \ldots \ldots \ldots \ldots \ldots \ldots$

6.0 LABORATORY ANALYSIS $\ldots \ldots \ldots \ldots \ldots \ldots \ldots \ldots \ldots \ldots \ldots \ldots \ldots \ldots$

7.0 THERMOLUMINESCENT DOSIMETERS $\ldots \ldots \ldots \ldots \ldots \ldots \ldots \ldots \ldots \ldots$

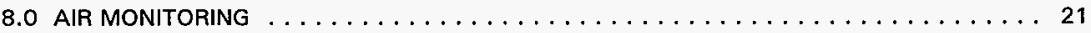

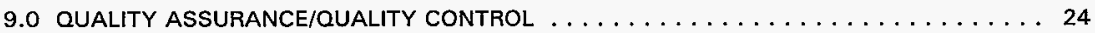

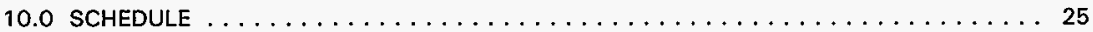

11.0 CHARACTERIZATION PLAN MODIFICATIONS $\ldots \ldots \ldots \ldots \ldots \ldots \ldots$

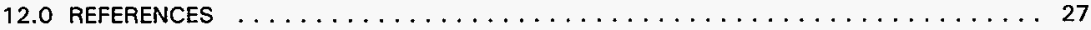




\section{LIST OF FIGURES}

1. Map of the Hanford Site and Location of the TWRS Phase I Demonstration Site . . . . . . . 2

2. Map of the 200 East Area Showing Location of the TWRS Phase I Demonstration Site . . . . 4

3. Map of TWRS Demonstration Site Showing Location of the Grout Vaults . . . . . . . . 5

4. 200 East Soil Sampling Locations for Routine Monitoring . . . . . . . . . . . . 10

5. Map Showing Location of the Three Sampling Sites Proximal to the W-465 Project . . . . 12

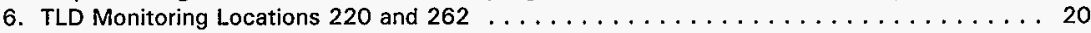

7. The 200 East Area Air Sampler Locations . . . . . . . . . . . . . . . . . . . . 22

\section{LIST OF TABLES}

1. Summary of Reported Soil Concentrations from Environmental Monitoring Sites Located Proximal (Upwind) to the $\mathrm{W}-465$ Site $(\mathrm{pCi} / \mathrm{g}) \ldots \ldots \ldots \ldots \ldots \ldots \ldots \ldots$

2. Summary of Radionuclide Concentrations for Areas near W-465 Site Collected during TWRS Phase I Demonstration Sampling (pCi/g) Compared with Maximum/Minimum Values for Entire

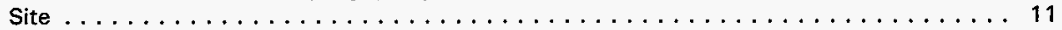

3. Sampie Analyses Summary . . . . . . . . . . . . . . . . . . . . 18

4. TLD Comparisons for Locations 220 and 262 from 1996 and 1997 (mrem/hr) . . . . . . 19

5. Ambient Air Monitoring Results -5 Year Averages $\left(\mathrm{pCi} / \mathrm{m}^{3}\right) \ldots \ldots \ldots \ldots \ldots \ldots$

\section{LIST OF TERMS}

$\begin{array}{ll}\text { DCG } & \text { derived concentration guide } \\ \text { DOE } & \text { U.S. Department of Energy } \\ \text { EIS } & \text { Environmental Impact Statement } \\ \text { GDA } & \text { Grout Disposal Area } \\ \text { GPS } & \text { Global Positioning System } \\ \text { GTF } & \text { Grout Treatment Facility } \\ \text { HEIS } & \text { Hanford Environmental Information System } \\ \text { HLW } & \text { high-level waste } \\ \text { ILAW } & \text { Immobilized Low Activity Waste } \\ \text { LLW } & \text { low-level waste } \\ \text { PUREX } & \text { Plutonium-Uranium Extraction (Facility) } \\ \text { OA } & \text { quality assurance } \\ \text { QC } & \text { quality control } \\ \text { RHO } & \text { Rockwell Hanford Operations } \\ \text { ROD } & \text { Record of Decision } \\ \text { TLD } & \text { thermoluminescent dosimeter } \\ \text { TWRS } & \text { Tank Waste Remediation System } \\ \text { URM } & \text { Underground Radioactive Material } \\ \text { WDOH } & \text { Washington State Department of Health } \\ \text { WHC } & \text { Westinghouse Hanford Company } \\ \text { WMNW } & \text { Waste Management Federal Services, Inc., Northwest Operations }\end{array}$


HNF-3211 Rev. 0

\section{SAMPLING AND ANALYSIS PLAN FOR THE PREOPERATIONAL ENVIRONMENTAL SURVEY FOR IMMOBILIZED LOW ACTIVITY WASTE (ILAW) PROJECT (W-465)}

\subsection{INTRODUCTION}

The U.S. Department of Energy (DOE) is the Federal agency responsible for waste management and environmental restoration at the Hanford Site near Richland, Washington (Figure 1). A major aspect of the waste management responsibility is the safe operation and containment of mixed radioactive and hazardous waste stored in 177 underground storage tanks. These include 149 single-shell tanks and 28 double-shell tanks that contain a total of 212 million L (56 million gal) of liquid, sludge, and saitcake.

The Tank Waste Remediation System (TWRS) Program was established in 1991 to treat, store, and dispose of the tank waste in a safe manner. To that end, a Final Environmental Impact Statement (EIS) (DOE 1996) and Record of Decision (ROD) (DOE 1997) were issued identifying the "preferred option" as tank waste vitrification and onsite disposal.

Phase I of this effort will embody a "proof of concept" phase for pretreatment and immobilization operations. This task has been designed for a private contractor to conduct this demonstration phase of the tank waste immobilization effort. Prior to the actual construction and operation of the facility and process in Phase IB, there will be a period for site characterization, planning, and conceptual design designated Phase IA.

Preoperational monitoring efforts are necessary to determine existing environmental conditions, assess the potential for contaminants, and evaluate potential risks and hazards prior to construction and operation of new facilities in accordance with DOE Order 5484.1 (DOE 1981).

The primary purpose and need for conducting a preoperational survey is to establish an environmental baseline and identify potential risks to public health and safety, and to the environment. Specifically these include prevention of the release of radioactive materials into the air or to the soil surrounding the Immobilized Low Activity Waste (iLAW) Facility, prevention of the potential migration of radionuclides through the soil column, reduction of occupational radiation exposure, and elimination of the risks to public and to workers from the deterioration of tank waste.

DOE Order 5400.1, General Environmental Protection Program, requires an environmental study before the startup of new facilities and processes. This DOE Order is expected to eventually become part of 10 CFR 834, Radiological Protection of the Public and the Environment.

\subsection{PURPOSE}

The sampling and monitoring efforts described herein will be conducted primarily in support of an environmental baseline to establish the preoperational conditions at the ILAW Project (W-465) Facilities sites in accordance with the requirements set forth in DOE Order 5400.1, Chapter IV (DOE 1988a). The data obtained from the baseline sampling activities will be used to verify the following objectives:

Identify baseline levels of contaminants in air, surface soils, vegetation, and the small-mammal community, as well as levels of external radiation. 
Figure 1. Map of the Hanford Site and Location of the TWRS Phase I Demonstration Site.

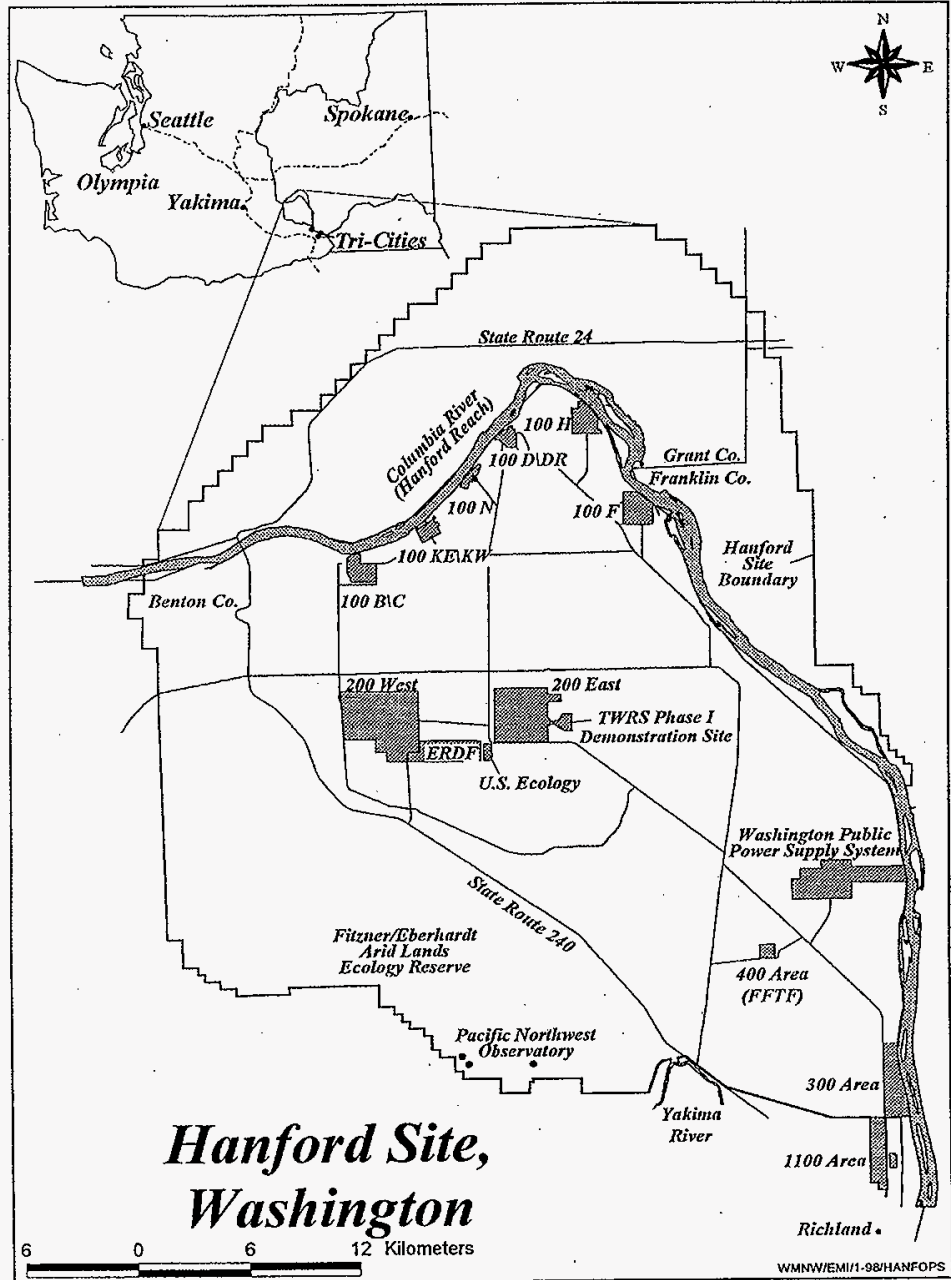


HNF-3211 Rev. 0

- Provide guidance for the development of personnel safety requirements during site development and operations.

- Allow for future determination of potential impacts to the environment from ILAW Project Facilities construction and operational activities.

- Provide guidance for development of monitoring and surveillance requirements within, and surrounding, the ILAW Project Facilities.

\subsection{PROJECT BACKGROUND}

The regulatory process conducted over the past few years to provide the direction for future actions regarding the tank wastes resulted in the issuance of the ROD (DOE 1997) with "Phased Implementation" as the preferred alternative.

The phased approach allowed for the retrieval and subsequent immobilization of the tank wastes through a Phase 1 demonstration effort lasting $\sim 10$ years and then using the information obtained to determine the best methodology for implementation of the full-scale production phase to last approximately 30 years.

One of the primary actions of the Phase I activities would be the construction of demonstration scale facilities to produce vitrified low-activity and high-activity waste for future disposal. It was determined that the pretreatment and immobilization operations for the low-level waste (LLW) and high-level waste (HLW) would be conducted by a private contractor. The produced ILAW would then be stored or disposed of in facilities developed by DOE and its contractors. Following treatment and immobilization of the tank wastes, the ILAW packages produced will be inspected and certified for safe transport and disposal by DOE and its contractors at the Hanford Site. The purpose of the ILAW storage and disposal projects is to receive the certified ILAW packages, transport them to various disposal sites located in the 200 Area plateau, and conduct disposal operations in a manner that permits retrieval (Shade 1997).

In order to conduct the above activities, a rather large site proximal to the underground storage tanks had to be located and evaluated. In 1986, an area 60 ha (147 acres) directly east of the 200 East Area was selected to serve as the Grout Disposal Area (GDA) for receiving vauits of grouted LLW produced by the Grout Treatment Facility (GTF). In order to characterize the site in 1987, surface soil samples and vegetation samples were collected, radiation surveys conducted, and 21 boreholes drilled at the site for vadose zone investigations and groundwater monitoring (Swanson et al. 1988). All of the data collected and analyzed verified that, with the exception of some low-level surface deposition of ${ }^{137} \mathrm{Cs}$ and ${ }^{90} \mathrm{Sr}$, the GTF was essentially a "clean" site. However, the grout project was canceled due to performance uncertainties.

During the site selection process for the TWRS Phase I Demonstration Site initiated in 1995 (Shord 1996), it became apparent that the location and the environmental data previously gathered indicating the GDA site could generally be considered "clean" made it a prime candidate for the location of the Phase I activities (Figure 2). It was subsequently selected in 1996.

Project W-465 will be responsible for the transportation and storage of the initial ILAW production estimated at approximately 5,000 packages. The site selected consists of the four existing grout vaults (Figure 3), which were not used by the Grout Treatment Demonstration. They are located immediately south of the single vault which contains grouted waste and has been posted as an Underground Radioactive Material (URM) area (Figure 3). 
HNF-3211 Rev. 0

Figure 2. Map of the 200 East Area Showing Location of the TWRS Phase I Demonstration Site.

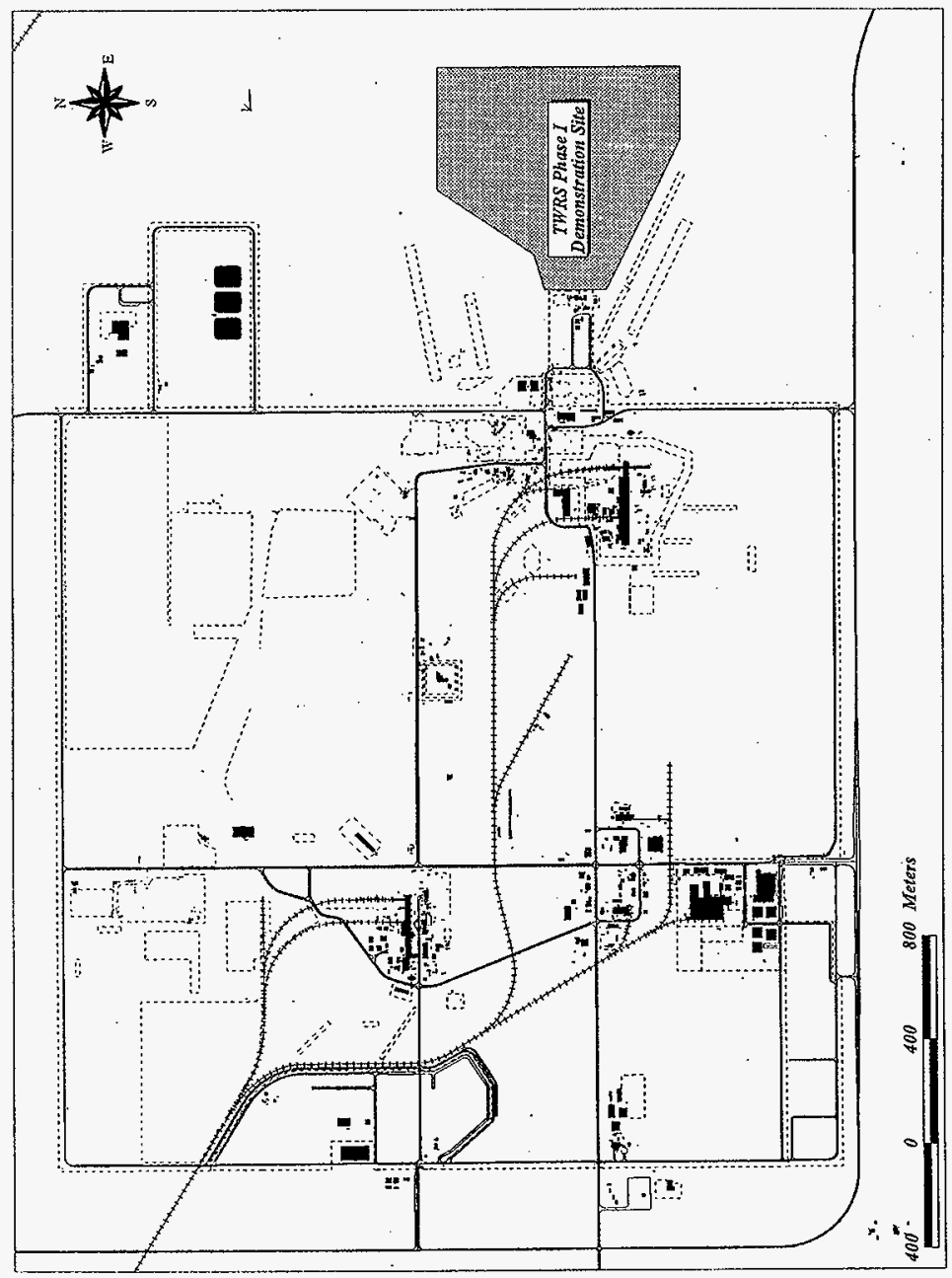


HNF-3211 Rev, 0

Figure 3. Map of TWRS Demonstration Site Showing Location of the Grout Vaults.

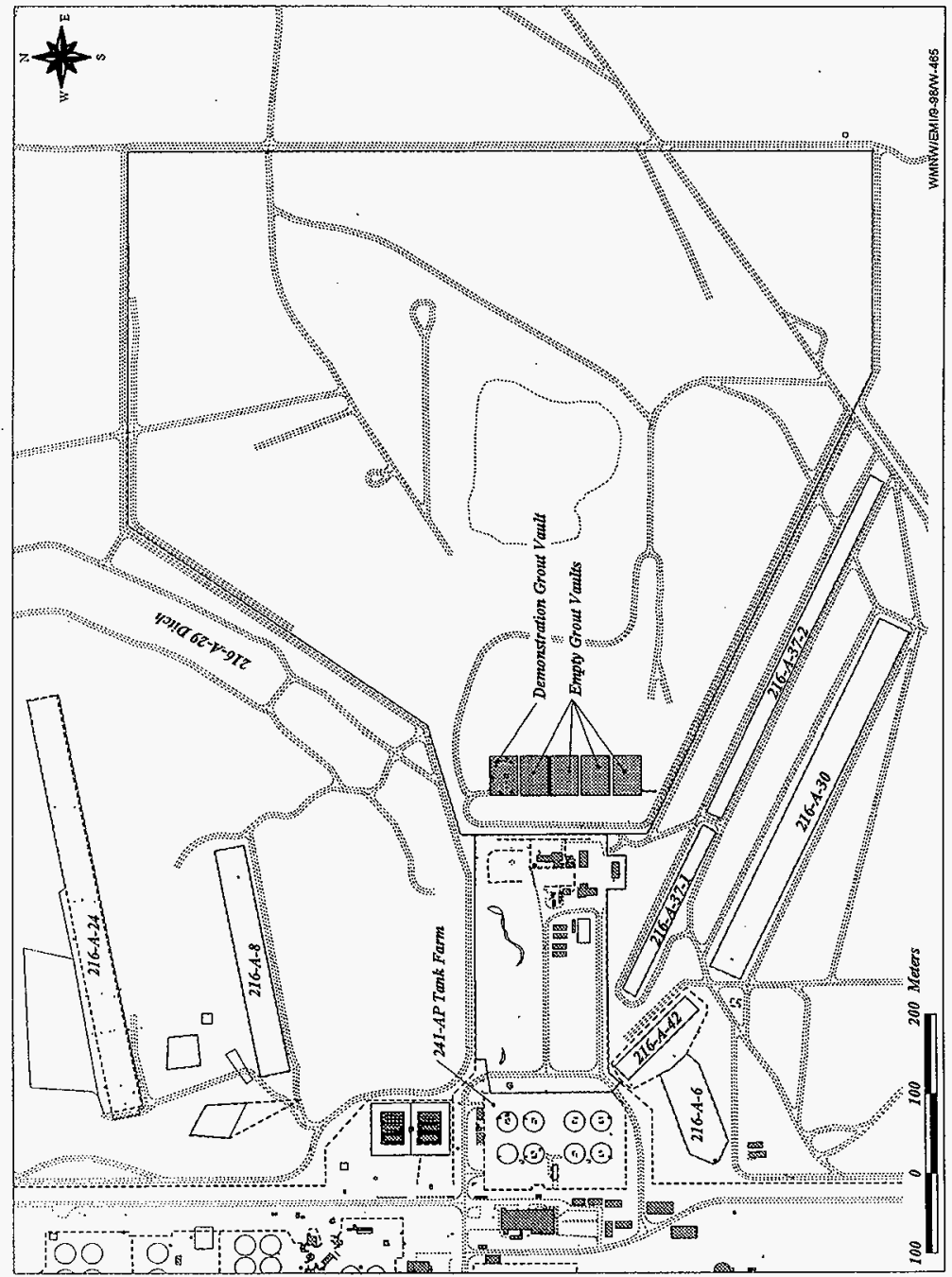


HNF-3211 Rev. O

\subsection{PROJECT SCOPE}

Prior to the startup of new facilities or modification of existing facilities, DOE requires the development of environmental baseline surveys for the protection of workers, the public, and the surrounding environment. This regulatory guidance is provided as part of the General Environmental Protection Program, DOE Order 5400.1 (DOE 1988a); the Environmental Protection, Safety and Health Protection Information Reporting Requirements, DOE Order 5484.1 (DOE 1981); and Radiation Protection of the Public and the Environment, DOE 5400.5 (DOE 1990a), as well as NUREG-1575, Multi-Agency Radiation Survey and Site Investigation Manual (MARSSIM) (NRC 1997).

The technical guidance for implementation of baseline surveys is provided in DOE/EH-0173T, Environmental Regulatory Guide for Radiological Effluent Monitoring and Environmental Surveillance (DOE 1991) and in the handbook entitled, Environmental Monitoring for Low Level Waste Disposal Sites (DOE 1990b).

Since the ILAW product will be accepted by DOE and disposed of on the Hanford Site, it will be subject to DOE Order 5820.2A, Radioactive Waste Management (DOE 1988b). The focus of the preoperational survey is to determine the existing environmental conditions in, and around, the proposed ILAW site for Project W-465.

\subsection{OBJECTIVES}

The primary objective of this preoperational survey is to establish an environmental baseline for the ILAW Project (W-465) Facilities. This will be done to determine the environmental conditions and establish background levels for contamination that may exist within the proposed site boundaries. This effort will provide documentation of the current levels of radioactive and selected chemical contaminants in the air, soils, vegetation, and small-mammal community at the site, as well as external radiation.

Specific concerns are related to the proximity of numerous Plutonium Uranium Extraction (PUREX) Facility cribs and the retired 216-A-29 Ditch (Snow's Canyon) along the boundaries of the ILAW Site (Figure 3). Other concerns include prevailing winds which could transport contaminated dust particles from waste sites located upwind, contaminated vegetation which could blow onto the site and scatter contaminated particles.

Elevated levels found during this preoperational survey, therefore, would be attributable to past practices and ongoing operations in the vicinity proximal to the location of the ILAW Project Facilities. The information obtained will provide guidance for the determination of potential contaminant transport pathways. This information also will assist in the development of the operational monitoring and surveillance system for early detection of potential impacts from other facility operations, or from ILAW Project Facilities operations to the surrounding environment. 
HNF-3211 Rev. 0

\subsection{SITE DESCRIPTION}

The Project W-465 ILAW Site is located directly east of the 200 East Area (Figure 2). Positioned along its northwestern and southwestern boundaries are a number of PUREX cribs and the retired process ditch, 216-A-29 (Figure 3). Located directly west of the site is the AP Tank Farm and the retired GTF. The area is surrounded by a security fence and numerous roads crisscross the area providing access to wells, boreholes, and other facilities (Figure 3 ).

The 200 East Area lies on a plateau in the central portion of the Hanford Site (Figure 1) approximately $11 \mathrm{~km}$ south of the Columbia River. This site contains various radionuclide and hazardous waste process facilities and waste disposal facilities (e.g., liquid waste cribs and solid waste burial grounds). The ecology of the 200 Areas was originally mature shrub-steppe desert characterized by such vegetation as big sagebrush (Artemisia tridentata) and Sandberg's bluegrass (Poa sandbergin). Large tracts of these habitat types exist outside these areas. However, the sagebrush habitat within the areas has generally been disturbed. These disturbed areas support a variety of plants such as introduced bunchgrasses (Agropyron spp.), invaders such as Russian thistie (Salsola kalh), cheatgrass (Bromus tectorum), and rabbitbrush (Chrysothamnus spp.).

Animal species observed in the 200 Areas, while still similar to those found before human use of the area (except certain invaders which have taken advantage of the changed habitats), are generally at reduced numbers where there is a reductions in vegetative cover and species. Native species include the long-billed curlew (Numenius americanus), the horned lark (Eremiphila alpestris), the burrowing owl (Athene cunicularia), the sage sparrow (Amphispiza belli), the loggerhead shrike (Lanius ludovicianus), the Great Basin pocket mouse (Perognathus parvus), the deer mouse (Peromyscus maniculatus), the Western harvest mouse (Reithrodontomys megalotis), the pocket gopher (Thomomys talpoides) the black-tailed jackrabbit (Lepus californicus), the badger (Taxidea taxis), and the coyote (Canis latrans).

Non-native species taking advantage of the altered habitats include the domestic pigeon (Columba /ivia) and the house mouse (Mus musculus). Additional information on existing habitat and associated species can be found in Neitzel (1997).

Twelve plant species considered to be endangered, threatened, or sensitive by the Washington Natural Heritage Program (1994) are known to survive on or near the Hanford Site, seven of which are upland species (Sackschewsky et al. 1992). The upland species are norther wormwood (Artemisia campestris spp. Borealis var. Wormskiodii) Hoover's desert parsley (Lomatium tuberosum), Pipers daisy (Erigeron piperianus), gray cryptantha (Cryptantha leucophea), Palouse milkvetch (Astragalus arrectus), and coyote tobacco (Nicotiana attenuata). Currently, none of the plant species are listed as federal threatened or endangered species. However, three local upland species are candidates for federal protection: (1) northern wormwood, (2) Hoover's desert parsley, and (3) Columbia milkvetch.

The bald eagle and peregrine falcon are the only federally listed threatened or endangered wildlife species occurring near the ILAW Project Facilities. Federal candidate species occurring near the ILAW Project include the ferrunginous hawk and loggerhead shrike. The pygmy rabbit, a shrubsteppe species listed as a federal candidate species and state threatened species, has not been observed on the Hanford Site since 1984 (Fitzner et al. 1992). The sage grouse, another federal candidate shrub-steppe species, has not been observed at the Hanford Site since the mid-1980's and probably no longer resides at the Site (Landeen et al. 1992). State listed threatened or endangered wildlife include the peregrine falcon and ferruginous hawk. State candidate species observed near the 200 Areas include the golden eagle, burrowing owl, sage thrasher, Swainson's hawk, striped whipsnake, Merriam's shrew, and sage sparrow (Stegen 1992). 


\section{HNF-3211 Rev. 0}

The specific areas comprising the proposed facilities are generally devoid of native vegetation, which over the years has been disturbed by various waste management activities, as well as construction of roads, buildings, storage basins, and other facilities. Thereby, the human activities and ongoing construction efforts have greatly reduced the likelihood that any protected species occur in the near vicinity. During the characterization activities, biologists will survey the area for any species of concern. 
HNF-3211 Rev. 0

\subsection{BACKGROUND ENVIRONMENTAL INFORMATION}

Environmental monitoring of radionuclide levels in the 200 East Area has been conducted by Rockwell Hanford Operations (RHO), Westinghouse Hanford Company (WHC), and Waste Management Federal Services, Inc., Northwest Operations (WMNW) in association with the burial grounds, liquid waste disposal facilities, and waste management activities conducted within and around these sites (Schmidt et al. 1990, 1992a, 1992b, 1993, 1994, 1995, 1996; Perkins et al. 1997, 1998).

\subsection{ENVIRONMENTAL MONITORING}

Soil and vegetative sampling has been conducted on a routine basis in the 200 Areas for a number of years (see above). Samples are presently collected from each location on a biennial (every other year) basis, and the analytical data are reviewed, analyzed, and reported in the annual monitoring report. Figure 4 shows the location of the soil sampling sites in the 200 East Area. None of the sampling locations is closer than $300 \mathrm{~m}$ to the Project W-465 Facilities and all are located upwind of the ILAW Site.

Table 1 provides a summary of reported values in soils at four adjacent locations for selected radionuclides of concern from 1993 through 1996. Sample location D073, located upwind of the Project W-465 Site along the prevailing wind direction, has demonstrated elevated ${ }^{137} \mathrm{Cs}$ $(60 \mathrm{pCi} / \mathrm{g})$ and ${ }^{90} \mathrm{Sr}(17 \mathrm{pCi} / \mathrm{g})$ concentrations during past sampling episodes.

Table 1. Summary of Reported Soil Concentrations from Environmental Monitoring Sites Located Proximal (Upwind) to the W-465 Site (pCi/g).

\begin{tabular}{|l|c|c|c|c|c|}
\hline \multirow{2}{*}{ Analyte } & \multicolumn{5}{|c|}{ Site location } \\
\cline { 2 - 6 } & Year & DO72 & D O73 & D074 & D076 \\
\hline${ }^{137} \mathrm{Cs}$ & 1996 & 0.3 & $\mathrm{NC}$ & 0.6 & 0.4 \\
\hline${ }^{90} \mathrm{Sr}$ & 1996 & 0.4 & $\mathrm{NC}$ & 0.09 & 0.3 \\
\hline${ }^{239 / 240} \mathrm{Pu}$ & 1996 & 0.003 & $\mathrm{NC}$ & 0.009 & 0.03 \\
\hline${ }^{137} \mathrm{Cs}$ & 1995 & $\mathrm{NC}$ & 0.6 & $\mathrm{NC}$ & $\mathrm{NC}$ \\
\hline${ }^{90} \mathrm{Sr}$ & 1995 & $\mathrm{NC}$ & 3.0 & $\mathrm{NC}$ & $\mathrm{NC}$ \\
\hline${ }^{239 / 240} \mathrm{Pu}$ & 1995 & $\mathrm{NC}$ & 0.01 & $\mathrm{NC}$ & $\mathrm{NC}$ \\
\hline${ }^{137} \mathrm{Cs}$ & 1994 & 0.9 & $\mathrm{NC}$ & 0.8 & 0.2 \\
\hline${ }^{90} \mathrm{Sr}$ & 1994 & 0.3 & $\mathrm{NC}$ & 0.2 & 0.09 \\
\hline${ }^{239 / 240} \mathrm{Pu}$ & 1994 & 0.009 & $\mathrm{NC}$ & 0.005 & 0.005 \\
\hline${ }^{137} \mathrm{Cs}$ & 1993 & 0.08 & 60.0 & 1.0 & 0.1 \\
\hline${ }^{90} \mathrm{Sr}$ & 1993 & 0.1 & 17.0 & 0.2 & 0.1 \\
\hline${ }^{239 / 240} \mathrm{Pu}$ & 1993 & 0.001 & 0.01 & 0.02 & 0.002 \\
\hline
\end{tabular}

NC $=$ Not collected. 
HNF-3211 Rev. 0

Figure 4. 200 East Soil Sampling Locations for Routine Monitoring.

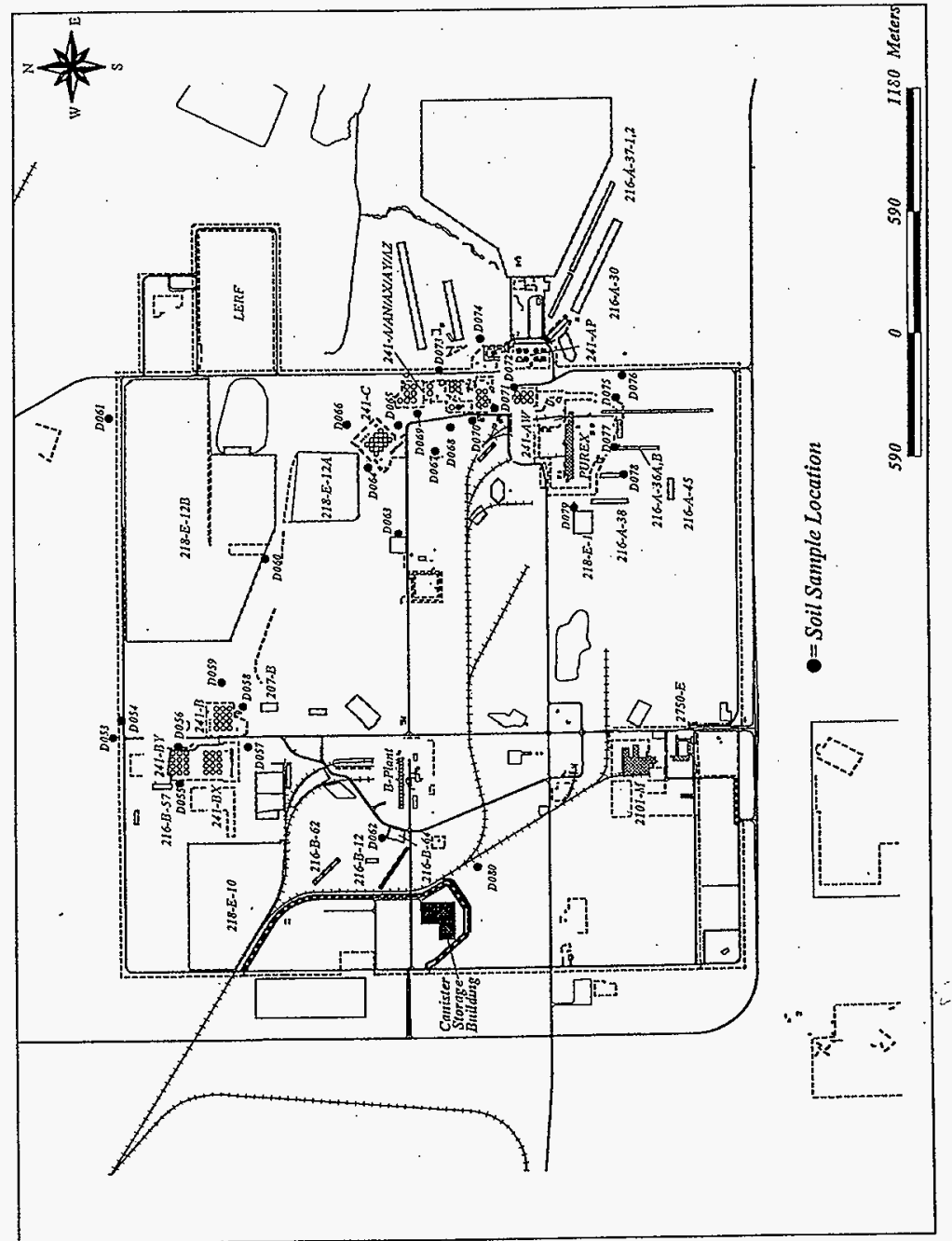


HNF-3211 Rev. 0

Preconstruction characterization of the TWRS Demonstration Site was recently completed (Mitchell et al. 1998). Three of the seventy-six locations sampled were located near the proposed Project $W-465$ Site (Figure 5). Table 2 provides a summary of selected radionuclide values in soil from these locations compared with the maximum and minimum values reported for all soil values.

Table 2. Summary of Radionuclide Concentrations for Areas near W-465 Site Collected during TWRS Phase I Demonstration Sampling $(\mathrm{pCi} / \mathrm{g})$ Compared with Maximum/Minimum Values for Entire Site.

\begin{tabular}{|l|c|c|c|c|c|}
\hline \multirow{2}{*}{$\begin{array}{c}\text { Site location } \\
\text { (sample ID) }\end{array}$} & \multicolumn{5}{|c|}{ Analyte } \\
\cline { 2 - 6 } & ${ }^{241} \mathrm{Am}$ & ${ }^{90} \mathrm{Sr}$ & ${ }^{137} \mathrm{Cs}$ & ${ }^{239 / 240} \mathrm{Pu}$ & ${ }^{234 / 238} \mathrm{U}$ \\
\hline 28 (BOM4R1) & 0.03 & 0.1 & 0.05 & 0.004 & 0.3 \\
\hline 34 (BOM4T3) & 0.02 & 0.2 & 0.02 & 0.02 & 0.3 \\
\hline 40 (BOM4P3) & 0.01 & 0.3 & $-0.007^{\circ}$ & 0.002 & 0.2 \\
\hline Maximum & 0.03 & 1.3 & 3.8 & 0.04 & 0.3 \\
\hline Minimum & 0.005 & 0.03 & 0.0 & 0.001 & 0.1 \\
\hline
\end{tabular}

* Value less than detection limits.

In summary, since the Project W-465 proposed facility comprises largely disturbed areas located proximal to a number of waste sites and active facilities, the utilization of the previously developed historical data will allow for collection of a minimal number of additional samples in the appropriately selected media. This determination is in concert with the recommendations of DOE Order 5400.1 to utilize existing data.

\subsection{CULTURAL RESOURCES}

The potential impacts of processing ILAW and storing it on a long-term basis have previously been reviewed (DOE 1996, DOE 1997). The grout facility is located inside the fenced portions of the site which have received extensive review (Chatters and Cadoret 1990). No known archaeological or historical sites are located within the proposed project site. However, sampling personnel will be informed to be on the lookout for any cultural resources and to notify the responsible personnel. 
HNF-3211 Rev. 0

Figure 5. Map Showing Location of the Three Sampling Sites Proximal to the W-465 Project.

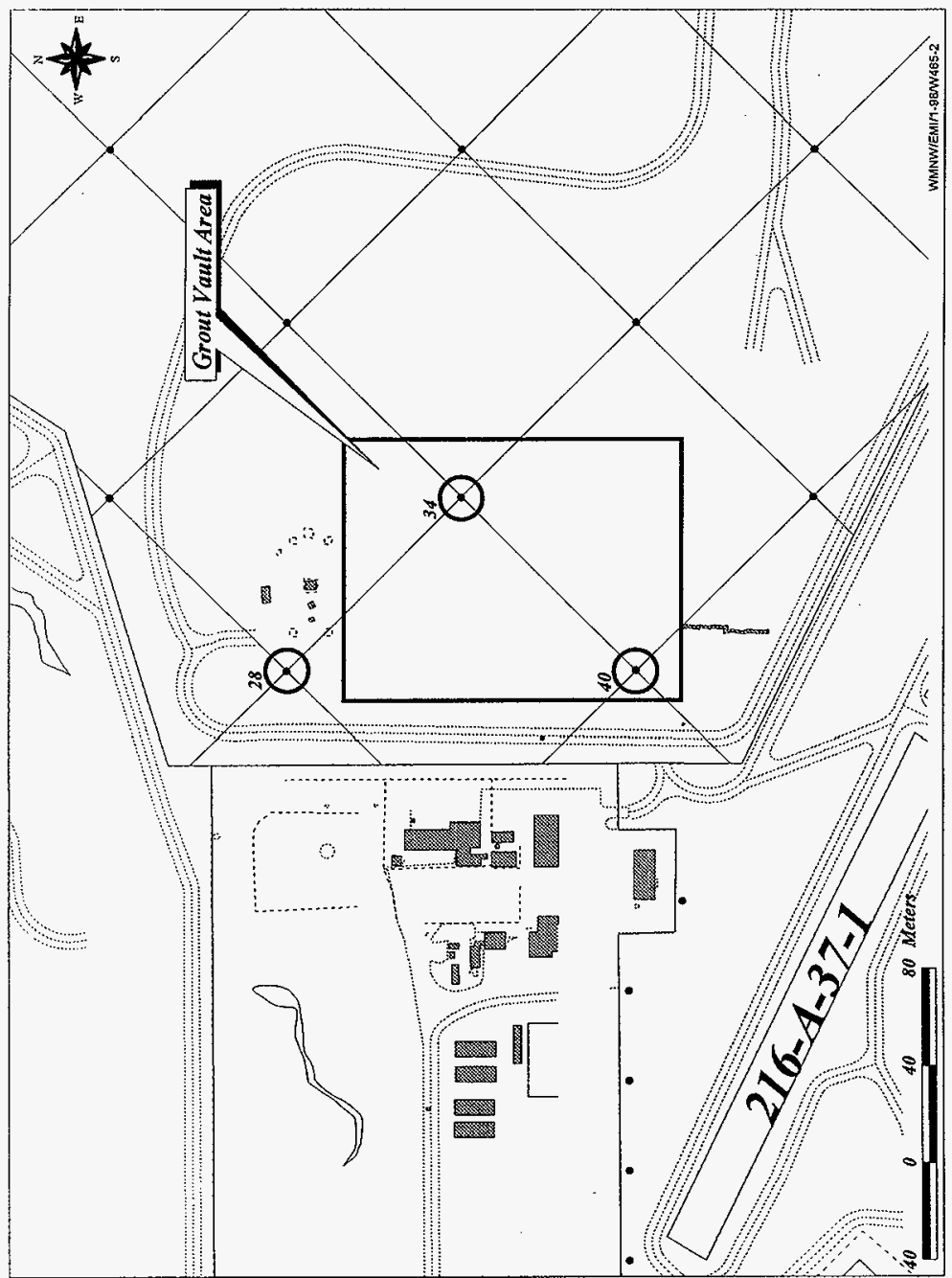


HNF-3211 Rev. 0

\subsection{GENERAL. REQUIREMENTS}

\subsection{HANFORD GENERAL REQUIREMENTS}

All personnel supporting this effort will have completed the applicable training and will perform work in accordance with the following:

- Operational Environmental Monitoring, WMNW-CM-004.

- Near-Facility Environmental Monitoring Quality Assurance Project Plan, HNF-EP-0538-3 (WMNW 1997).

- Environmental Training, HNF-PRO-459.

- Quality Assurance Program Plans, HNF-PRO-261.

- $\quad$ Safety and Environmental Reference Manual, WMNW-SERM-001.

- $\quad$ Site-specific health and safety plans, and Activity Hazard Analysis.

- Site-specific facility orientation.

\subsection{ILAW PROJECT (W-465) FACILITIES GENERAL REQUIREMENTS}

The requirements and procedures applicable to the Project W-465 Project Facilities field characterization activities are specified in the Sampling Services Procedures Manual, ES-SSPM-001. Applicable guidelines and procedures may include the following:

- SP 1-1, "Chain of Custody."

- SP 1-2, "Project and Sample Identification for Sampling Services."

- SP 1-3, "Control of Certificates of Analysis."

- SP 1-5, "Field Logbooks."

- SP 2-1, "Bottle Preservation."

- SP 2-5, "Laboratory Cleaning of Sampling Equipment."

- SP 2-6, "Sample Packaging and Shipping."

- SP 4-1, "Solid Sampling."

- SP 6-1, "Calibration and Control of Monitoring Instruments."

The field activities will conform to the requirements of a site-specific safety assessment to be completed before the initiation of sampling activities. A pre-job safety meeting, including any personnel associated with the field work, wili be held before the performance of the sampling effort. Comments and concerns will be addressed and resolved at that time.

An Activity Hazard Analysis Checklist will be developed. 


\section{HNF-3211 Rev. 0}

A tailgate safety meeting will be held at the job site each day prior to commencement of operations. 
HNF-3211 Rev. 0

\subsection{SAMPLING AND FIELD ACTIVITIES}

Sampling efforts for the W-465 Project Facilities will focus on the collection of environmental data and media which include air, thermoluminescent dosimeters (TLDs Iexternal radiation]), surface soil, vegetation, plant litter, cryptogams (mosses and lichens), and small mammals. Historical information has been reviewed and evaluated to determine the types of samples needed, the analyses required for potential contaminants of concern, and prospective sample site selection.

\subsection{OBJECTIVES}

The primary objectives of the preoperational survey include the following: (1) determining current levels of radionuclides in environmental media attributable to previous and ongoing operations of other waste management facilities in the area; (2) providing data that will demonstrate the lack of significant environmental impact during ILAW Project Facilities operations, or conversely, indicate when corrective actions may be necessary; (3) characterizing existing levels of radionuclides in the selected media and other environmental pollutants for comparison of past and future trends for the enhancement of routine operational monitoring; and (4) identifying potential pathways for human exposure and environmental impacts.

\subsection{SAMPLE SITE SELECTION}

Before the initiation of sampling activities, a detailed map of the W-465 Project Facilities will be obtained that shows the location of existing and proposed buildings, facilities, and other structures. The location of nearby waste sites, such as burial grounds, cribs, ditches, and ponds, also will be noted in the field logbook. Using this information, the sites will be reconnoitered to determine the prime areas for the location of sampling points. Each sample site will be marked with a surveyor's stake and noted on a map, which will be included in the field logbook.

All of the staked locations will be surveyed with a Trimble 4000 SSi 9 channel Global Positioning System (GPS) receiver and reduced to Washington State Plane (south zone) North American Datum of 1983; 1991 adjustment in meters.

\subsection{FIELD SCREENING}

Field screening will be utilized to assist in the selection of samples to be submitted for laboratory analyses. Soils from potential sampling locations will be observed for discoloration, excessive moisture, or other anomalies. Any soils demonstrating these characteristics will be screened utilizing an organic vapor monitor and results recorded in the field logbook. Soil exhibiting positive readings for organic constituents may be submitted for analyses. Collected samples will also be screened for radioactivity utilizing a Geiger-Muller counter and an alpha detector.

\subsection{EQUIPMENT AND SUPPLIES}

The following materials and equipment may be required to perform the outlined tasks:

- $\quad$ Plastic sampling jars.

- Glass sampling jars.

- Sample jars labels.

- Protection gloves. 
- Ice chest with wet or "blue" ice.

- Absorbent (vermiculite) for shipping.

- Permanent marking pens.

- Safety glasses.

- Sampling devices (trowels, spoons, augers, shoveis).

- Plastic sealer bags.

- Evidence tape.

- Measuring tape.

- Other items as needed.

\subsection{SAMPLE MEDIA}

\subsubsection{Soils}

Soil samples will be collected and preserved in accordance with the requirements outlined in SP 4-1, "Solid Sampling: Soil and Sediment Sampling."

\subsubsection{Vegetation}

Deep-rooted shrubs, and possibly grasses, will be collected in accordance with "Vegetation Sampling" (WMNW-CM-004).

\subsubsection{Small Animals}

The collection and preservation of small mammal samples will be conducted following the guidance provided in "Animal Sampling" (WMNW-CM-004).

\subsection{FIELD LOGBOOKS}

Field activities will be recorded in a field logbook according to the protocols outline in SP 1-5, "Field Logbooks." Entries will be made in ink, signed, and dated, Photographs will be taken during sampling and to document any unusual circumstances encountered during the investigation.

\subsection{CHAIN OF CUSTODY}

Chain of custody records will be maintained in accordance with the requirements of SP 1-1, "Chain of Custody/Sample Analysis Request." The chain of custody form will establish the documentation necessary to ensure the traceability of the sample from time of collection until disposal.

\subsection{SAMPLE HANDLING}

Following collection, samples will be controlled in accordance with the requirements outlined in SP 2-6, "Sample Packaging and Shipping." All samples will be labeled, sealed, and placed in a container for preservation on ice or other appropriate cooling medium. 
HNF-3211 Rev. 0

\subsubsection{Sample Labels}

The Hanford Environmental Information System (HEIS) is used to track the sample and laboratory data obtained during environmental investigations conduced under this description of work. Each sample will be identified and labeled with a unique HEIS sample number. HEIS numbers will be assigned in the field per SP 1-2, "Project and Sample Identification for Sampling Services." The sample location and corresponding HEIS numbers will be documented in the field logbook.

\subsubsection{Sample Analysis Report}

An approved laboratory selected by Sample Data and Laboratory Administration will be used to conduct laboratory analyses. The request for appropriate analyses will be included on the sample analysis request form as provided in SP 1-1, "Chain of Custody/Sample Analysis Request." Laboratory specific forms may be utilized in lieu of the site form and will be made available by the laboratory.

\subsubsection{Shipping}

Shipping requirements will conform with SP 2-6, "Sampling Packaging and Shipping."

\subsection{DECONTAMINATION}

Hand-held equipment used for the direct collection of samples will have been previously cleaned in accordance with SP 2-5, "Laboratory Cleaning of Sample Equipment." 
HNF-3211 Rev. 0

\subsection{LABORATORY ANALYSIS}

SP 2-1, "Bottle Preservation," provides general guidance for containers and preservation requirements. The contractor laboratory may request modifications to these recommendations as long as the quality of the data is not compromised. Sample containers are purchased precleaned from a supplier providing certification of internal laboratory procedures.

Samples collected for radionuclide analyses will be transported to the contract laboratory for processing. These samples will be analyzed for gamma spectroscopy to include ${ }^{241} \mathrm{Am}$. Additional analyses will include ${ }^{90} \mathrm{Sr}$, as well as isotopic plutonium and uranium.

The remaining samples will be transported to a contractor laboratory for analysis of metals, anions, and other analytes as requested. A complete list is provided in the sample analyses summary (Table 3 ).

Table 3. Sample Analyses Summary.

\begin{tabular}{|c|c|c|c|c|}
\hline Parameter/analysis & $\begin{array}{l}\text { Analytical } \\
\text { methods }\end{array}$ & Container $1 /$ volume & Preservation & Holding time \\
\hline ICP metals & 6010 & \multirow{5}{*}{$\mathrm{G} 125 \mathrm{~mL}$} & \multirow{5}{*}{ Cool to $4{ }^{\circ} \mathrm{C}$} & 6 months \\
\hline Arsenic & 7060 & & & 6 months \\
\hline Lead & 7421 & & & 6 months \\
\hline Mercury & 7471 & & & 28 days \\
\hline Cyanide & & & & \\
\hline Anions & \multirow{3}{*}{ EPA 300.0} & \multirow{3}{*}{$P / G 250 \mathrm{~mL}$} & \multirow{3}{*}{ Cool to $4{ }^{\circ} \mathrm{C}$} & \\
\hline $\mathrm{SO}_{4}, \mathrm{~F}, \mathrm{Cl}$ & & & & 28 days \\
\hline $\mathrm{NO}_{2}, \mathrm{NO}_{3}, \mathrm{PO}_{4}$ & & & & 48 hours \\
\hline Gamma scan & ITAS-RD-3219 & \multirow{5}{*}{ P/G $2000 \mathrm{~mL}$} & \multirow{5}{*}{ None } & \multirow{5}{*}{6 months } \\
\hline${ }^{90} \mathrm{Sr}$ & ITAS-RD-3204 & & & \\
\hline${ }^{241} \mathrm{Am}$ & ITAS-RD-3220 & & & \\
\hline $238,239 / 240 \mathrm{Pu}$ & ITAS-RD-3209 & & & \\
\hline Isotopic uranium & ITAS-RD-4200 & & & \\
\hline
\end{tabular}

'Container types: $P=$ plastic (polyethylene).

$\mathrm{G}=$ glass. 
HNF-3211 Rev. 0

\subsection{THERMOLUMINESCENT DOSIMETERS}

A network of TLDs is positioned in and around the 200 Areas to monitor dose rates from external radiation sources (primarily gamma rays). The environmental TLDs measure dose rates from all types of external radiation sources. These include cosmic radiation, naturally occurring radiation in air and soil, and fallout from nuclear weapons testing, as well as any contribution from the Hanford Site activities. These outside radiation sources cause an estimated $\pm 20 \%$ deviation in TLD analyses. The results are reported in units of millirems per year (mrem/yr).

The TLD measurements are taken to determine dose rates in the operations area environment. From these data, the contribution of the Hanford Site activities to the dose rates in these areas can be discerned.

The Hanford Site uses the Harshaw TLD system, which includes the Harshaw 8807 dosimeter and the Harshaw 8800 TLD reader. The TLD packaging, which uses an "O ring" seal, protects the TLDs from light, heat, moisture, and dirt. The TLDs are place one meter (approximately $3 \mathrm{ft}$ ) aboveground at each location. The TLDs are placed near active and inactive surface-water disposal sites and near facilities (tank farms, active cribs, and the facility fence line). Changing conditions in the vicinity of the TLD sample locations, such as remediation activities, removal or storage of radioactive material, and tank farm operations may also cause fluctuations in TLD analyses over time. The TLDs are exchanged each calendar quarter.

Figure 6 shows the location of the two TLD monitoring locations (\#220 and \#262) which are both located approximately $100 \mathrm{~m}$ from the northernmost grout vault. Table 4 provides a summary of the values recorded for 1996 and 1997 . The average for all of the 200 Area TLDs in 1997 was $109 \mathrm{mrem} / \mathrm{yr}$.

Additional TLDs will be located on the boundary of the W-465 Project Facifities in accordance with the guidance provided in WMNW-CM-004.

Table 4. TLD Comparisons for Locations 220 and 262 from 1996 and 1997 (mrem/hr).

\begin{tabular}{|c|c|c|c|}
\hline Site ID & 1996 & 1997 & Percent Change \\
\hline 220 & 96 & 94 & $-2 \%$ \\
\hline 262 & 84 & 80 & $-5 \%$ \\
\hline
\end{tabular}


HNF-3211 Rev. 0

Figure 6. TLD Monitoring Locations 220 and 262.

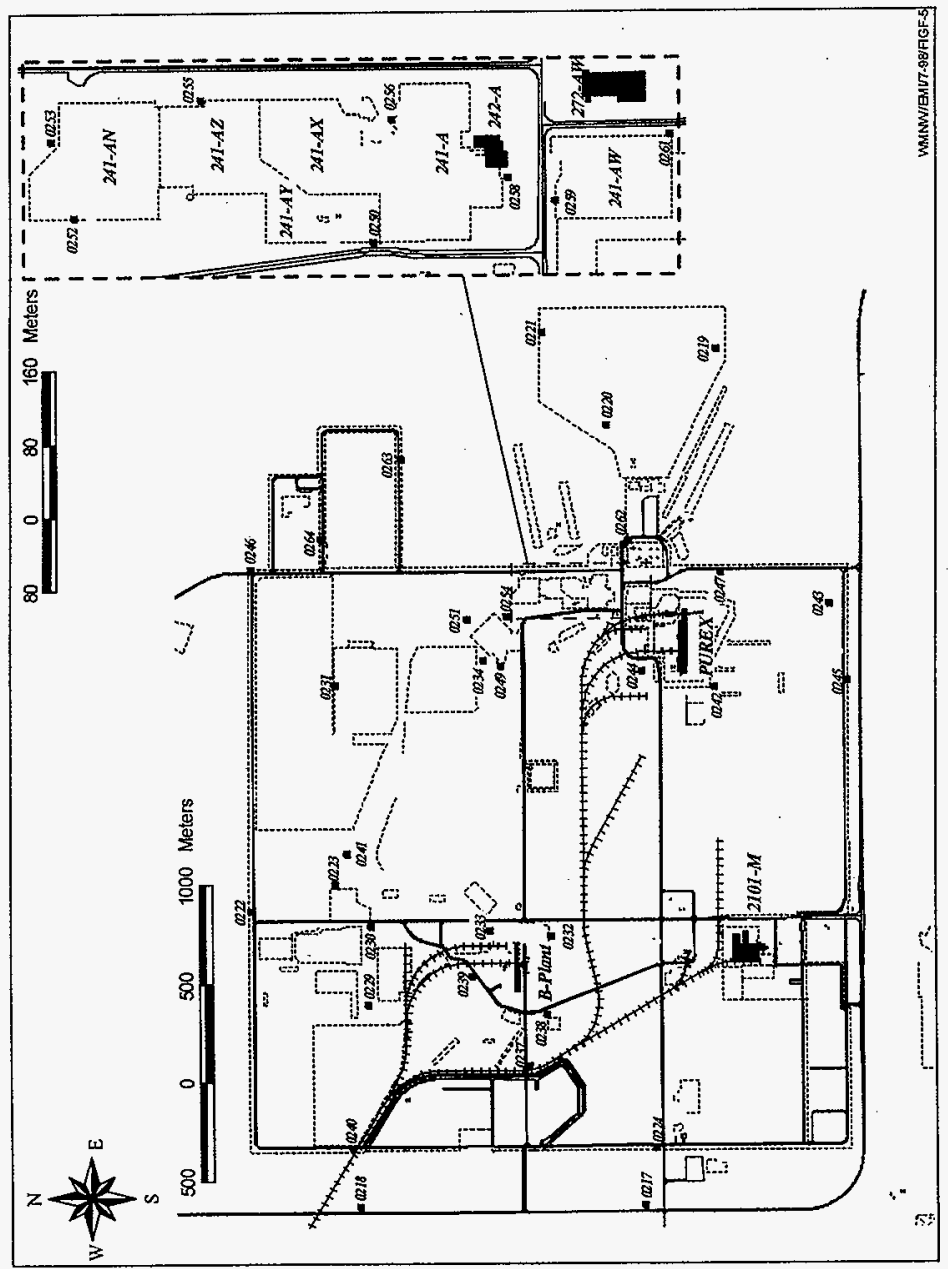


HNF-3211 Rev. 0

\subsection{AIR MONITORING}

Ambient air monitoring is conducted to determine baseline concentrations of radionuclides in the operations areas, to assess the impact of operations on the local environment, and to monitor diffuse emissions from sources located within the operations area. These measurements also provide an indication of facility and/or project performance and are used to demonstrate compliance with environmental protection criteria.

The placement of air monitoring stations takes into consideration potential source terms as well as prevailing wind direction. Meteorological conditions are monitored continuously by Pacific Northwest meteorology stations, which are strategically positioned in and around the Hanford Site.

Hanford Site air samplers operate at a flow rate of $0.056 \mathrm{~m}^{3} / \mathrm{min}\left(2 \mathrm{ft}^{3} / \mathrm{min}\right)$, drawing a sample through a $47 \mathrm{~mm}(2 \mathrm{in}$.), open-faced filter about $2 \mathrm{~m}(6 \mathrm{ft})$ aboveground. Typically, sample filters are exchanged biweekly, held one week (to allow for decay of the short-lived natural radioactivityl, and then sent to the analytical laboratory for initial analysis of total alpha and total beta activity. These initial analyses serve as an indicator of potential environmental problems.

The filters are stored until the end of the six month sampling period, then segregated and composited by sample location (or as deemed appropriate) for specific radionuclide analysis. Segregating and compositing air filters by site provides a larger sample size and, thus, a more sensitive and accurate measurement of the concentration of airborne radionuclides.

To help assess the impact of Site operations, monitoring results are compared to DOE derived concentration guides (DCG), to the results obtained from the distant communities of Yakima and Sunnyside (reported by the Pacific Northwest Site Environmental Surveillance Program) and to data acquired from distant station N-981 located at the Wye Barricade.

Figure 7 shows the locations of the ambient air samplers in the 200 East Area. When compared to historical, prevailing wind directions, all of the existing sampling stations are situated such that most of the time they are upwind of the ILAW Site.

Table 5 provides five-year summaries of radioanalytical data collected from the nearby samplers $\mathrm{N}-158, \mathrm{~N}-977$ and $\mathrm{N}-985$ (1993 through 1997) and from the distant communities' sampling stations (1992 through 1996), as well as the corresponding DCG for each radionuclide. Many of the average results have statistical uncertainties above $100 \%$ and/or average concentrations less than zero; both of these indicate that the radionuclide was below its analytical detection level. Sampler $\mathrm{N}-158$ does exhibit positive values for ${ }^{137} \mathrm{Cs},{ }^{234} \mathrm{U}$, and ${ }^{238} \mathrm{U}$. The most frequently detected radionuclide during the period was ${ }^{234} \mathrm{U}$.

The available data is adequate to be used to establish the "background" concentrations of radionuclides in air near the ILAW Site. To adequately determine effects during facility operation, it is recommended that additional downwind samplers be utilized. 
HNF-3211 Rev. 0

Figure 7. The 200 East Area Air Sampler Locations.

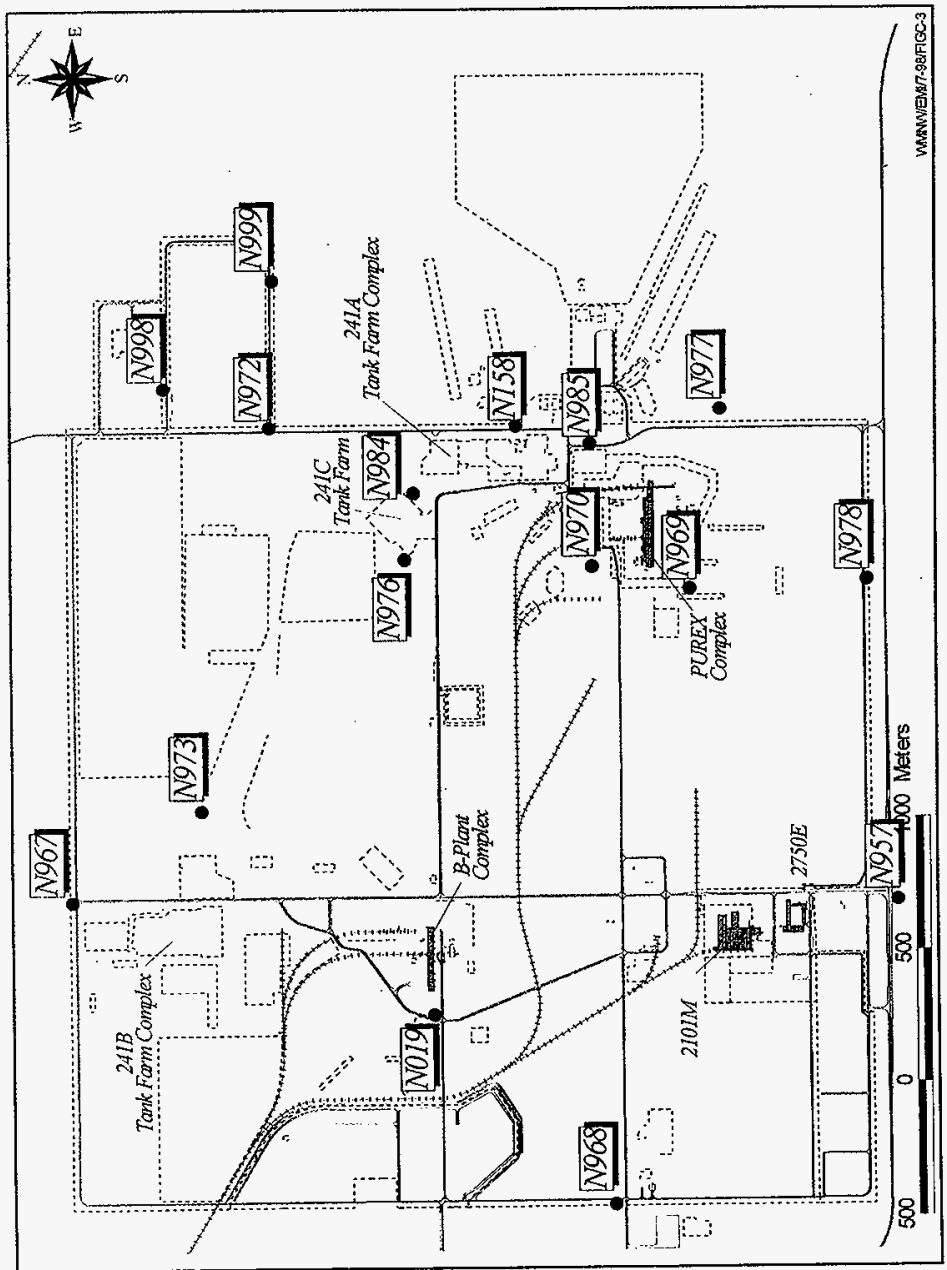


HNF-3211 Rev. 0

Table 5. Ambient Air Monitoring Results - 5 Year Averages $\left(\mathrm{pCi} / \mathrm{m}^{3}\right)$.

\begin{tabular}{|l|l|l|l|l|l|}
\hline Radionuclide & \multicolumn{1}{|c|}{$\mathrm{N}-158$} & $\mathrm{~N}-977$ & $\mathrm{~N}-985$ & $\begin{array}{c}\text { Distant } \\
\text { Community }\end{array}$ & DCG \\
\hline${ }^{60} \mathrm{Co}$ & $-1.24 \mathrm{E}-04 \pm 148 \%$ & $-4.0 \mathrm{E}-05 \pm 325 \%$ & $-1.6 \mathrm{E}-04 \pm 217 \%$ & $5.9 \mathrm{E}-05 \pm 110 \%$ & $8.00 \mathrm{E}+01$ \\
\hline${ }^{90} \mathrm{Sr}$ & $2.5 \mathrm{E}-04 \pm 160 \%$ & $1.5 \mathrm{E}-04 \pm 180 \%$ & $1.3 \mathrm{E}-04 \pm 162 \%$ & $-5.0 \mathrm{E}-06 \pm 240 \%$ & $9.00 \mathrm{E}+00$ \\
\hline${ }^{137} \mathrm{Cs}$ & $3.2 \mathrm{E}-04 \pm 68 \%$ & $9.1 \mathrm{E}-05 \pm 158 \%$ & $2.1 \mathrm{E}-04 \pm 125 \%$ & $1.7 \mathrm{E}-05 \pm 329 \%$ & $4.00 \mathrm{E}+02$ \\
\hline${ }^{234} \mathrm{U}$ & $1.5 \mathrm{E}-05 \pm 56 \%$ & $1.2 \mathrm{E}-05 \pm 183 \%$ & $1.7 \mathrm{E}-05 \pm 58 \%$ & $2.3 \mathrm{E}-05 \pm 16 \%$ & $9.00 \mathrm{E}-02$ \\
\hline${ }^{235} \mathrm{U}$ & $9.0 \mathrm{E}-06 \pm 133 \%$ & $4.4 \mathrm{E}-06 \pm 236 \%$ & $6.1 \mathrm{E}-06 \pm 122 \%$ & $2.0 \mathrm{E}-06 \pm 60 \%$ & $1.00 \mathrm{E}-01$ \\
\hline${ }^{238} \mathrm{U}$ & $2.0 \mathrm{E}-05 \pm 56 \%$ & $1.7 \mathrm{E}-05 \pm 60 \%$ & $8.3 \mathrm{E}-06 \pm 114 \%$ & $3.5 \mathrm{E}-05 \pm 60 \%$ & $1.00 \mathrm{E}-01$ \\
\hline${ }^{238} \mathrm{Pu}$ & $-1.1 \mathrm{E}-06 \pm 263 \%$ & $-8.5 \mathrm{E}-07 \pm 457 \%$ & $-1.2 \mathrm{E}-06 \pm 249 \%$ & $3.2 \mathrm{E}-07 \pm 100 \%$ & $3.00 \mathrm{E}-02$ \\
\hline${ }^{239 / 240} \mathrm{Pu}$ & $3.7 \mathrm{E}-06 \pm 186 \%$ & $1.1 \mathrm{E}-05 \pm 157 \%$ & $3.8 \mathrm{E}-06 \pm 132 \%$ & $5.9 \mathrm{E}-07 \pm 78 \%$ & $2.00 \mathrm{E}-02$ \\
\hline
\end{tabular}

DCG = Derived concentration guide. 
HNF-3211 Rev. 0

\subsection{QUALITY ASSURANCE/QUALITY CONTROL}

Quality assurance/quality control (QA/OC) samples are collected to provide for determination of field and laboratory QA/OC levels (HNF-EP-0538-3, WMNW 1997). Three types of $(\mathrm{OA} / \mathrm{OC})$ samples will be collected in the field:

- Duplicate samples will be collected from the same location, then submitted as two separate samples for separate analysis at the same laboratory.

- Split samples will be collected from the same locations, but will be sent to two different laboratories; one sample will be sent to the primary laboratory, the second will be sent to an independent laboratory.

- An equipment blank of clean silica sand will be submitted to verify the cleanliness of the decontaminated sampling equipment.

The number of $\mathrm{QA} / \mathrm{OC}$ samples required will conform to one each of the above designated samples collected/processed per 20 soil samples as a minimum. QA/OC samples required for vegetation will be limited to duplicate and split samples. Because of the uniqueness of the media, small mammals will not be submitted for QA/OC purposes.

Personnel from the Washington State Department of Health (WDOH) (Office of Radiation Protection) will collect split samples of soil and vegetation. In order to reduce costs, the samples sent to the WDOH laboratory will be considered to represent the split samples described above. 
HNF-3211 Rev. 0

\subsection{SCHEDULE}

Sample of the multiplicity of media identified will require a coordination of the efforts, depending on growth patterns of vegetation, animal activity, and availability of the media. If field conditions permit, it would be preferable to sample all the required media at the site over a three to five day period. That synchronization of effort will be the goal of the sample scheduling of this project. However, if environmental conditions are not favorable, sampling may take place over several days.

In order to meet the requirements of DOE 5400.1 to include seasonal variability, verification samples may be collected from selected sample sites. These will allow comparisons with the radionuclide and metals data obtained previously. 
HNF-3211 Rev. 0

\subsection{CHARACTERIZATION PLAN MODIFICATIONS}

Under field conditions, the optimal aspects of preliminary sample design are not always achievable. Factors influencing these efforts can be equipment malfunction or breakdown, weather conditions, improper equipment, soil conditions, physical barriers to sampling equipment, and overly optimistic evaluation of capabilities. Because of unforeseen field conditions, modifications to the planned activity may be necessary as decided by the Field Team Leader.

To ensure efficient and timely completion of tasks, minor field changes can be made in the field by the person in charge of the particular activity. Minor field changes are those that have no adverse effects on the technical adequacy of the job or the work schedule. Such changes will be documented in the daily log books that are maintained in the field.

Major changes to this plan will be submitted on a Project Change Form. The change will require at least the verbal approval of the Field Team Leader and the project coordinator. The change will be filed, and a copy will be kept with the project file. 


\subsection{REFERENCES}

10 CFR 834, 1998, "Radiological Protection of the Public and the Environment," Code of Federal Regulations, as amended.

Chatters, J. C., and N. A. Cadoret, 1990, Archaeological Survey of the 200-East Area 200-West Area, Hanford Site, Washington, PNL-7264, Pacific Northwest Laboratory, Richland, Washington.

DOE, 1997, Record of Decision for the Tank Waste Remediation System, Hanford Site, Richland, Washington, 6450-01-P, U.S. Department of Energy, Washington, D.C.

DOE, 1996, Tank Waste Remediation System, Hanford Site, Final Environmental Impact Statement, DOE/EIS-0189, U.S. Department of Energy, Washington, D.C.

DOE, 1991, Environmental Regulatory Guide for Radiological Effluent Monitoring and Environmental Surveillance, DOE/EH-0173T, U.S. Department of Energy, Washington, D.C.

DOE, 1990a, Radiation Protection of the Public and the Environment, DOE Order 5400.5 , U.S. Department of Energy, Washington, D.C.

DOE, 1990b, Low Level Waste Management Handbook Series: Environmental Monitoring for Low Leve/ Waste Disposal Sites, DOE-LLW-13Tg, Rev. 2, Washington, D.C.

DOE, 1988a, General Environmental Protection Program, DOE Order 5400.1, U.S. Department of Energy, Washington, D.C.

DOE, 1988b, Radioactive Waste Management, DOE Order 5820.2A, U.S. Department of Energy, Washington, D.C.

DOE, 1981, Environmental Protection, Safety, and Health Protection Information Reporting Requirements, DOE Order 5484.1, U.S. Department of Energy, Washington, D.C.

EPA, 1986, Test Methods for Evaluating Solid Waste, SW-846, Third Edition, EPA/Office of Solid Waste and Emergency Response, U.S. Environmental Protection Agency, Washington, D.C.

ES-SSPM-001, Sampling Services Procedures Manual, Waste Management Federal Services, inc., Northwest Operations, Richland, Washington.

Fitzner, R. E., S. G. Weiss, and J. A. Stegen, 1992, Biological Assessment for Threaterned and Endangered Wildiffe Species, Related to CERCLA Characterization Activities, WHC-EP-0513, Westinghouse Hanford Company, Richland, Washington.

HNF-PRO-261, Quality Assurance Program Plans, Fluor Daniel Hanford, Inc., Richland, Washington.

HNF-PRO-459, Environmental Training, Fluor Daniel Hanford, Inc., Richland, Washington.

Landeen, D. S., A. R. Johnson, and R. M. Mitchell, 1992, Status of Birds at the Hanford Site in Southeastern Washington, WHC-EP-0402, Rev. 1, Westinghouse Hanford Company, Richland, Washington. 
Mitchell, R. M., D. L. Edwards, B. M. Markes, R. K. Price, K. D. Reynolds, W. R. Thackaberry, C. J. Chou, V. G. Johnson, D. G. Horton, S. P. Reidel, K. A. Bergstrom, and T. H. Mitchell, 1998, TWRS Phase / Privatization Site Preconstruction Characterization Report, HNF-2067, Fluor Daniel Hanford, Richland, Washington.

Neitzel, D.A., 1997, Hanford Site National Environmental Policy Act (NEPA) Characterization, PNL-6415, Rev. 9, Pacific Northwest National Laboratory, Richland, Washington.

NRC, 1997, Multi-Agency Radiation Survey and Site Investigation Manual (MARSSIMi, NUREG-1575, icollaboratively developed by the U.S. Environmental Protection Agency, U.S. Department of Energy, U.S. Department of Defense, and U.S. Nuclear Regulatory Commission), Washington, D.C.

Perkins, C. J., A. R. Johnson, B. M. Markes, S. M. McKinney, and R. M. Mitchell, 1998, Hanford Site Near-Facility Environmental Monitoring Annual Report, Calendar Year 1997, HNF-EP-0573-6, Waste Management Federa! Services, Inc., Northwest Operations for Fluor Daniel Hanford, Inc., Richland, Washington.

Perkins, C. J., A. R. Johnson, B. M. Markes, S. M. McKinney, and R. M. Mitchell, 1997, Hanford Site Near-Facility Environmental Monitoring Annual Report, Calendar Year 1996, HNF-EP-0573-5, Waste Management Federal Services, Inc., Northwest Operations for Fluor Daniel Hanford, Inc., Richland, Washington.

Sackschewsky, M. R., D. S. Landeen, G. I. Baird, W. H. Richard, and J. L. Downs, 1992, Vascular Plants of the Hanford Site, WHC-EP-0554, Westinghouse Hanford Company, Richland, Washington.

Schmidt, J. W., J. W. Fassett, V. G. Johnson, R. M. Mitchell, B. M. Markes, S. M. McKinney, K. J. Moss, and C. J. Perkins, 1996, Westinghouse Manford Company Operational Environmental Monitoring Annual Report, Calendar Year 1995, WHC-EP-0573-4, Westinghouse Hanford Company, Richland, Washington.

Schmidt, J. W., J. W. Fassett, A. R. Johnson, V. G. Johnson, B. M. Markes, S. M. McKinney, K. J. Moss, C. J. Perkins, and L. R. Richterich, 1995, Westinghouse Hanford Company Operational Environmental Monitoring Annual Report, Calendar Year 1994. WHC-EP-0573-3, Westinghouse Hanford Company, Richland, Washington.

Schmidt, J. W., A. R. Johnson, B. M. Markes, S. M. McKinney, and C. J. Perkins, 1994, Westinghouse Hanford Company Operational Environmental Monitoring Annual Report, Calendar Year 1993, WHC-EP-0573-2, Westinghouse Hanford Company, Richland, Washington.

Schmidt, J. W., A. R. Johnson, S. M. McKinney, and C. J. Perkins, 1993, Westinghouse Hanford Company Operational Environmental Monitoring Annual Report, Calendar Year 1992, WHC-EP-0573-1, Westinghouse Hanford Company, Richland, Washington.

Schmidt, J. W., A. R. Johnson, S. M. McKinney, and C. R. Webb, 1992a, Westinghouse Hanford Company Environmental Surveillance Annual Report - 200/600 Areas, Calendar Year 1990, WHC-EP-0145-4, Westinghouse Hanford Company, Richland, Washington.

Schmidt, J. W., A. R. Johnson, S. M. McKinney, C. J. Perkins, and C. R. Webb, 1992b, Westinghouse Hanford Company Environmental Surveillance Annual Report - 200/600 Areas, Calendar Year 1991, WHC-EP-0573, Westinghouse Hanford Company, Richland, Washington. 
Schmidt, J. W., C. R. Huckfeldt, A. R. Johnson, and S. M. McKinney, 1990, Westinghouse Hanford Company Environmental Surveillance Annual Report - 200/600 Areas, Calendar Year 1989, WHC-EP-0145-2, Westinghouse Hanford Company, Richland, Washington.

Shade, J. W., 1997, TWRS Retrieval Area Disposal Mission: Immobilized Low-Activity Waste Disposal Plan, HNF-1517, Fluor Daniel Hanford, Inc., Richland, Washington.

Shord, A. L., 1996, Tank Waste Remediation System Complex Site Evaluation Report, WHC-SD-WM-SE-021, Westinghouse Hanford Company, Richland, Washington.

SP 1-1, "Chain of Custody," Sampling Services Procedures Manual, ES-SSPM-001, Waste Management Federal Services, Inc., Northwest Operations, Richland, Washington.

SP 1-2, "Project and Sample Identification for Sampling Services," Sampling Services Procedures Manual, ES-SSPM-001, Waste Management Federal Services, Inc., Northwest Operations, Richland, Washington.

SP 1-3, "Control of Certificates of Analysis," Sampling Services Procedures Mamual, ES-SSPM-001, Waste Management Federal Services, Inc., Northwest Operations, Richland, Washington.

SP 1-5, "Field Logbooks," Sampling Services Procedures Manual, ES-SSPM-001, Waste Management Federal Services, Inc., Northwest Operations, Richland, Washington.

SP 2-1, "Bottle Preservation," Sampling Services Procedures Manual, ES-SSPM-001, Waste Management Federal Services, inc., Northwest Operations, Richland, Washington.

SP 2-5, "Laboratory Cleaning of Sampling Equipment," Sampling Services Procedures Manual, ES-SSPM-001, Waste Management Federal Services, Inc., Northwest Operations, Richland, Washington.

SP 2-6, "Sample Packaging and Shipping," Sampling Services Procedures Manual, ES-SSPM-001, Waste Management Federal Services, Inc., Northwest Operations, Richland, Washington.

SP 4-1, "Solid Sampling," Sampling Services Procedures Manual, ES-SSPM-001, Waste Management Federal Services, Inc., Northwest Operations, Richland, Washington.

SP 6-1, "Calibration and Control of Monitoring Instruments," Sampling Services Procedures Manual, ES-SSPM-001, Waste Management Federal Services, Inc., Northwest Operations, Richland, Washington.

Stegen, J. A., 1992, Biological Assessment for State Candidate and Monitor Wildlife Species Related to CERCLA, WHC-SD-EN-EE-009, Westinghouse Hanford Company, Richland, Washington.

Swanson, L. C., D. C. Weeks, S. P. Luttrell, R. M. Mitchell, D. S. Landeen, A. R. Johnson, and R. C. Roos, 1988, Grout Treatment Facility Environmental Baseline and Site Characterization Report, WHC-EP-0150, Westinghouse Hanford Company, Richland, Washington.

Washington Natural Heritage Program, 1994, Endangered, Threatened, and Sensitive Vascular Plants of Washington. Washington State Department of Natural Resources, Olympia, Washington.

WMNW-CM-004, Operational Environmental Monitoring, Waste Management Federal Services, Inc., Northwest Operations, Richland, Washington. 
HNF-3211 Rev. O

WMNW-SERM-001, Safety and Environmental Reference Manual, Waste Management Federal Services, Inc., Northwest Operations, Richland, Washington.

WMNW, 1997, Near-Facility Environmental Monitoring Quality Assurance Project Plan, HNF-EP-0538-3, Waste Management Federal Services, Inc., Northwest Operations, Richland, Washington. 


\section{DISTRIBUTION SHEET}

\begin{tabular}{|c|c|c|c|c|c|}
\hline \multirow{2}{*}{$\begin{array}{l}\text { To } \\
\text { M. L. Deffenbaugh }\end{array}$} & \multirow{2}{*}{\multicolumn{3}{|c|}{$\begin{array}{l}\text { From } \\
\text { R. M. Mitchell }\end{array}$}} & \multicolumn{2}{|c|}{ Page 1 of 1} \\
\hline & & & & \multicolumn{2}{|c|}{ Date $09 / 22 / 98$} \\
\hline \multirow{2}{*}{\multicolumn{4}{|c|}{$\begin{array}{l}\text { Project Title/Work Order } \\
\text { W-465 Sampling and Analysis Plan }\end{array}$}} & \multirow{2}{*}{\multicolumn{2}{|c|}{$\begin{array}{ll}\text { EDT No. } & 622966 \\
\text { ECN No. } & \text { NA }\end{array}$}} \\
\hline & & & & & \\
\hline \multicolumn{2}{|l|}{ Name } & $\begin{array}{l}\text { Text } \\
\text { With All } \\
\text { Attach. }\end{array}$ & Text Only & $\begin{array}{l}\text { Attach./ } \\
\text { Appendix } \\
\text { Only }\end{array}$ & $\begin{array}{l}\text { EDT/ECN } \\
\text { Only }\end{array}$ \\
\hline $\begin{array}{l}\text { P. K. Brockman } \\
\text { K. C. Burgard } \\
\text { T. A. Carlson } \\
\text { M. L. Deffenbaugh (3 copies) } \\
\text { L. P. Diediker } \\
\text { J. J. Dorian } \\
\text { A. R. Johnson } \\
\text { B. M. Markes } \\
\text { F. M. Mann } \\
\text { R. M. Mitchel1 (5 copies) } \\
\text { D. J. Moak } \\
\text { G. L. Parsons } \\
\text { C. J. Perkins } \\
\text { C. A. Peterson } \\
\text { Central Files }\end{array}$ & $\begin{array}{l}H 1-11 \\
\text { S4-45 } \\
S 4-45 \\
S 4-45 \\
H 6-36 \\
H 1-13 \\
H I-13 \\
H 1-13 \\
R 1-04 \\
H 1-13 \\
H 1-11 \\
S 4-45 \\
H 1-13 \\
S 4-45 \\
B 1-07\end{array}$ & $\begin{array}{l}x \\
\chi \\
\chi \\
\chi \\
x \\
x \\
x \\
x \\
x \\
x \\
x \\
x \\
x \\
\chi \\
x\end{array}$ & & & \\
\hline
\end{tabular}

DOE/RL Reading Room

Hanford Technical Library
$H 2-53 . X$

P8-55

$x$
$x$

